Swarthmore College

Works

1988

\title{
Cellular Politics: Ernest Everett Just, Richard B. Goldschmidt, And The Attempt To Reconcile Embryology And Genetics
}

Scott F. Gilbert

Swarthmore College, sgilber1@swarthmore.edu

Follow this and additional works at: https://works.swarthmore.edu/fac-biology

Part of the Biology Commons

Let us know how access to these works benefits you

\section{Recommended Citation}

Scott F. Gilbert. (1988). "Cellular Politics: Ernest Everett Just, Richard B. Goldschmidt, And The Attempt To Reconcile Embryology And Genetics". American Development Of Biology. 311-346.

https://works.swarthmore.edu/fac-biology/353

This work is brought to you for free by Swarthmore College Libraries' Works. It has been accepted for inclusion in Biology Faculty Works by an authorized administrator of Works. For more information, please contact myworks@swarthmore.edu. 


\section{Scott F. Gilbert}

\section{Cellular Politics: Ernest Everett Just, Richard B. Goldschmidt, and the Attempt to Reconcile Embryology and Genetics}

Reflecting on embryology in the 1930s, Johannes Holtfreter stated:

We managed more or less successfully to keep our work undisturbed by humanity's strife and struggle around us and proceeded to study the plants and animals, and particularly, the secrets of amphibian development. Here, at least, in the realm of undespoiled Nature, everything seemed peaceful and in perfect order. It was from our growing intimacy with the inner harmony, the meaningfulness, the integration, and the interdependence of the structures and functions as we observed them in dumb creatures that we derived our own philosophy of life. It has served us well in this continuously troublesome world.'

The attempts to reintegrate embryology and genetics during the last years of the 1930s represent the last chapter in the emergence of American biology. When had American biology finished "emerging"? I suspect that stage was reached when it had successfully resisted the last attempts to reintegrate it into European-dominated traditions of inquiry. For genetics, this occurred in the late 1930s when Richard B. Goldschmidt and Ernest Everett Just separately countered the American school of genetics with European alternatives. Goldschmidt and Just both attempted to place genetics into a physiological framework. Goldschmidt was the director of the genetics section of the Kaiser Wilhelm Institute before fleeing the Nazis and coming to America in 1936. For Goldschmidt, the "static genetics" of T. H. Morgan, centered on individual particulate genes, was to be replaced by "physiological genetics" wherein the gene did not exist as an individual unit, and its activity, not its location, was the focus of research. 
E. E. Just was a black American embryologist who had left America in 1931 to work in Europe. His emphasis on the importance of cytoplasmic factors in heredity was well within the European framework of Carl F. Correns, Fritz von Wettstein, and Alfred Kühn. For both Goldschmidt and Just, the relationship between nucleus and cytoplasm became a key issue. For American geneticists, Morgan had used the nuclear envelope as a conceptual and disciplinary barrier. Geneticists study the transmission of genetic traits within the nucleus, embryologists study the expression of those traits in the cytoplasm. This division was to allow each discipline to proceed separately. Because European geneticists did not recognize that boundary, the separation of genetics from embryology did not occur in Europe, where the dominant perspective of biology came from physiology. Just and Goldschmidt, two "American" biologists with European affinities, each tried to return American genetics to the physiological traditions. As Just pointed out in 1936, only when the genes are placed "within the domain of physiology" could "genetics become a branch of biology."

\section{A House Divided}

Thomas Hunt Morgan was an embryologist who inadvertently founded the gene theory in $1911 .{ }^{2}$ While the Mendelian geneticists had been analyzing the segregation of characters from one generation to another, Morgan investigated whether changes in the nuclear composition of an organism affected its development. He began asking this question of ctenophore eggs and sea urchin embryos, and the results convinced him that it was the cytoplasm that controlled development and inheritance. Through 1910, Morgan remained the major American critic of the Sutton-Boveri synthesis of Mendelism and cytology. Only when his Drosophila studies demonstrated that factors for eye color, body color, wing shape, and sex all segregated with the X-chromosome did Morgan reluctantly propose the physical linkage of these genetic traits.

The years 1911 to 1915 saw the emergence of a new discipline-genetics. Although genetics would eventually come to influence all areas of biological study, the first to feel its effects was its parent discipline, embryology, for the experimental embryology pioneered by Roux and Weismann in the 1880s saw the problems of inheritance and development as the same. Even as late as 1910, embryologist Morgan stated, "We have come to look upon the problem of heredity as identical to the problem of development." 3 However, in the years following 1910, Morgan drove a wedge into embryology, splitting it into two divisions comprising the embryologists and the new geneticists.

Geneticists could not develop their own discipline without constructing a research program separate from that of the rest of the embryologists. To this end, Morgan employed Wilhelm Johannsen's distinction between genotype 
and phenotype. Johannsen had argued that heredity should only be considered as the transmission of genetic traits from one generation to another. The emergence of the phenotype was of secondary importance and belonged to the realm of embryology. Sapp and Allen have shown that Johannsen's distinctions allowed Morgan to shift his attention from the cytoplasmic realm of the phenotype to that of the nuclear genotype. ${ }^{4}$

In the mature formulation of his genetics, The Theory of the Gene, Morgan stated that much unwarranted criticism of genetics had come "from confusing the problems of genetics with those of development." This separation was extremely important for the emergence of genetics as a new discipline, and he argued that "the sorting out of characters in successive generations can be explained at present without reference to the way in which the gene affects the developmental process." Thus, Morgan had separated the transmission of hereditary traits (genetics) from the expression of those traits (embryology). ${ }^{5}$

Yet Morgan himself never completely abandoned his primary devotion to embryology, and he returned to active embryological research after he left Columbia University. Already one year after The Theory of the Gene was printed, Morgan published Experimental Embryology. These two excellent textbooks demonstrated Morgan's continued knowledge and expertise in both areas. Therefore, when his Embryology and Genetics appeared in 1934, those scientists who desired the resynthesis of the two disciplines had high hopes. Yet, although this volume provided a survey of both genetics and embryology, it did not attempt to integrate them. Boris Ephrussi, who was later to play a major role in such reunifying efforts, recalled his own response.

I said I found the book very interesting, but I thought that the title was misleading because he did not try to bridge the gap between embryology and genetics as he had promised in the title. Morgan looked at me with a smile and said, 'You think the title is misleading! What is the title?' 'Embryology and Genetics,' I said. 'Well,' he asked, 'is not there some embryology and some genetics?' This shows how polarized I was on the gap between embryology and genetics, and how anxiously I was waiting for somebody to bridge it. ${ }^{6}$

Many biologists wished to reconcile the two fields. The small community of mechanistic biologists felt embarrassed by the widening gap between two of its most successful disciplines. Speaking of the separate courses taken by genetics and developmental physiology, F. R. Lillie had remarked that: "There can be no doubt, I think, that the majority of geneticists, and many [developmental] physiologists certainly, hope for and expect a reunion. The spectacle of the biological sciences divided permanently into two camps is evidently for them too serious a one to be regarded with satisfaction." ?

However, after mentioning various attempts to reconcile the two fields, Lillie pessimistically concluded that developmental physiology and genetics 
must remain separate. "Those who desire to make genetics the basis of physiology of development will have to explain how an unchanging complex can direct the course of an ordered developmental stream. . . . The dilemma at which we have arrived appears to be irresolvable at present."

Like many embryologists, Lillie had good reason for being suspicious of genetics as an explanation for development. First, as the quotation illustrates, the chromosomal repertoire was believed by geneticists to be constant in every cell. Yet development was defined by cellular change. "It would, therefore, appear to be self-contradictory to attempt to explain embryonic segregation by behavior of genes which are ex-hype the same in every cell." Second, heredity was perceived to be controlled by nuclear chromosomes. Development on the other hand was manifest in the cytoplasm. As Lillie stated, "The germ exhibits the duality of nucleus and cytoplasm; the geneticist has taken the former for his field, the embryologist the latter." 8

Differentiation was seen as caused by intercellular relationships (a cell becoming a different structure when placed in a different part of an embryo), and such relationships were "mediated through the cytoplasm, not through the nucleus." Lillie thought that the genes constituted the basis of a physiological reaction system to the environment but were not responsible for specifying particular developmental characteristics.

These were the points that Morgan failed to address in his 1934 book. Indeed, the synthesis had not progressed very far in the seven years since Lillie's essay. Morgan noted that "the interlocking of these two has become a subject of absorbing interest" and that his book would attempt to "point out in a simple way their interrelations." However, Morgan's goals were actually more superficial. He was not so much interested in discussing "interrelations" as he was "points of contact." The latter was Morgan's own metaphor and aptly described his views. ${ }^{9}$ Throughout this book, Morgan portrayed the two disciplines as exclusive spheres touching at a common point. This "common meeting place of embryology and genetics was found in the relationship between the hereditary units in the chromosomes, the genes, and the protoplasm of the cell where the influence of the genes comes to visible expression." This relationship was expressed simply: "The initial differences in the protoplasmic regions may be supposed to affect the activity of the genes. The genes will then in turn affect the protoplasm, which will start a new series of reciprocal reactions. In this way, we can picture to ourselves the gradual elaboration and differentiation of the various regions of the embryo." ${ }^{10}$

This framework of nucleocytoplasmic interaction was not new but was an updating of Hans Driesch's classic embryological statement from 1894. " Furthermore, Morgan could offer no direct experimental evidence in favor of this hypothesis, and he returned to explanations used at the turn of the century by E. B. Wilson to explain the nuclear role in programming the cytoplasm. Thus, 
Morgan's analysis of sinistral coiling of the snail's shell - the only developmental mutant discussed in his book-is almost identical to Wilson's analysis of molluscan development in 1894 and 1904. Some material is postulated to pass from the nucleus to become active in the cytoplasm. In the case of snail coiling, the gene is active in the production of the oocyte cytoplasm itself.

Although Morgan's book is generally a review of the two divergent disciplines, he did present a new and very liberal interpretation of the gene. The two fundamental properties of such a unit, he wrote, were its power to grow and divide and its power to cause changes in the chemical and physical nature of the cytoplasm. The evidence for the former rested on the cytological demonstration of chromosomal replication, whereas the evidence for the latter, admittedly circumstantial, was that changes in hereditary characteristics can be traced back to particular loci on particular chromosomes. He did not hold to the view of "genic balance" - that is, that all the genes are active in every cell and that the phenotype is the summed product of all the individual influences. In that view, a mutation or environmental assault would perturb this equilibrium in one way or another. This concept had the advantage of fitting into current models of general physiology and homeostasis, and many embryologists (such as Lillie) tended to assume it. Morgan, however, thought that this view was "quite inadequate to explain the sequence of changes through which the embryo passes." Morgan also did not believe that "different batteries of genes come into action as development proceeds," for this was inconsistent with Driesch's data wherein nuclei given different positions in the embryo directed the differentiation in accord with their new locations. So Morgan did not propose any mechanism for differentiation that would work according to his model of nucleocytoplasmic interaction. However, the last page of this book suggests that the nuclear genes may not be the unchangeable entities that geneticists had (and until very recently still have) assumed. "It is, however, conceivable that the genes also are building up more and more, or are changing in some way, as development proceeds in response to that part of the protoplasm in which they come to lie, and that these changes have a reciprocal influence on the protoplasm." ${ }^{12}$ Morgan's refusal to integrate genetics and embryology and his extremely flexible, even epigenetic, view of the gene opened the way for others to attempt the synthesis.

\section{The Rival Professions}

Although embryologists in the 1920 s generally hoped that genetics would return to the fold, by the mid 1930s many embryologists were reacting against the new genetics. The geneticists had become too successful. Jan Sapp, and Diane Paul and Barbara Kimmelman (this volume) show that with the interest 
in applied breeding techniques (in both animal husbandry, plant breeding, and eugenics), genetics quickly asserted itself as the premier biological science in America. The years from 1915 to 1932 were characterized by "the establishment of university chairs of genetics; by the founding of an academic journal, Genetics . . . and by the emergence of a purely academic genetics society, quite separate from the American Genetics Association. The Genetics Society of America was founded in 1932." 13

The geneticists believed they had mastered the mechanisms of chromosome transmission and were now looking in the direction of gene expression. ${ }^{14}$ Expression, of course, is epigenetic development and had been left to the embryologists to unravel. But the embryologists had their own set of problems and interests, and entering the nuclear realm to identify the products of these so-called genes was not one of them. The organizer experiments from Hans Spemann's laboratory, the intercellular gradient theories of C. M. Child, the intracellular gradients discovered by J. Runnstrom and Sven Hörstadius, the limb development fields of R. G. Harrison, and the pluripotency of neural crest cells shown by Benjamin Willier and Mary Rawles were fascinating phenomena worthy of any embryologist's attention. Thus, a few geneticists started to venture into the realm of gene expression. Most notably, Ephrussi and G. W. Beadle began their analysis of the genetic control of the development of eye pigment. ${ }^{15}$

In 1936, two years after Morgan's book, a joint session of the American Society of Zoologists, the American Society of Naturalists, and the Genetic Society of America was conducted on "Genetics and Development." Like Morgan's book before, the discussions had some genetics and some development, but there was little "crossover." The discussants were E. E. Just, E. W. Sinnott, G. W. Beadle, and V. C. Twitty. Just began his lecture by limiting his discussion to the embryological events of fertilization and cleavage as if those were the only embryonic stages where such a discussion was possible. "In discussing the phenomena of the process of animal embryogenesis . . from which we may attempt to derive a theory of development and heredity, I must obviously limit myself to those changes that take place before the embryo is delineated." ${ }^{16} \mathrm{He}$ relegated Mendelian nuclear characters to secondary status as those finishing touches occurring after the cytoplasm had built the basis of the embryo, and he argued that neither nucleus nor cytoplasm, alone, is a functioning biological entity. Sinnott noted that it was impossible to know how a gene controlled something until one had learned what a gene controlled. His lecture, on the genetic control of shape in gourds and melons, concentrated on the problem of allometric growth. Beadle reviewed the inheritance of eye color in Drosophila, showing that diffusible substances involved in pigment production are deficient in certain mutants. Last, Twitty summarized the genetics of pigment pattern in salamanders. Here, inter- 
specific hybrids and grafts showed that both the egg and sperm influence pigment development and distribution.

Not only was there no agreement among the speakers, but the embryologists were hostile to the notion that genetics and embryology might be two approaches to study the same phenomenon. Harrison, in his review of the session, noted that "the embryologist . . . is more concerned with the larger changes in the whole organism and its primitive systems of organs than with the lesser qualities associated with gene action." Just put it more succinctly, stating that he was more interested in how the embryo made a back than in the formation of the bristles on the back and more interested in the developmental construction of the eye than in the synthesis of eye pigments. ${ }^{17}$

Immediately after this session, Harrison, as outgoing chairman of the section on zoological sciences of the American Association for the Advancement of Science, presented a lecture on "Embryology and Its Relations." It is obvious that he did not think that the realms of embryology and genetics were coextensive, and he wanted to keep the geneticists on their own turf.

Now that the necessity of relating the data of genetics to embryology is generally recognized and the "Wanderlust" of geneticists is beginning to urge them in our direction, it may not be inappropriate to point out a danger in this threatened invasion.

The prestige of success enjoyed by the gene theory might easily become a hindrance to the understanding of development by directing our attention solely to the genom, whereas cell movements, differentiation, and in fact all developmental processes are actually effected by the cytoplasm. ${ }^{18}$

Harrison was not alone in his fears for embryology. N. J. Berrill, one of the founders of the Growth Symposium that later became the Developmental Biology Society, recently characterized the geneticists of the 1930s as "marauding intruders." 19 He likened their behavior to that of a corporation that aggressively subsumed other companies. "The geneticists," he said, "felt that they had all the answers, and all my life, they've been pushing." Berrill should know, because he had to defend embryology at McGill University against the encroachments by geneticist C. L. Huskins. Huskins wanted to unite the zoology, botany, and genetics departments with genetics on top.

This fight was synecdochical for the larger battle, for it was largely one of methodological orthodoxy versus methodological pluralism. The geneticists claimed that development could be approached as an epiphenomenon of genetic control and therefore that genetics could best obtain the answers to developmental questions. In fact, all biology was seen as epiphenomenal of the genetic processes, so it was natural for them to assert that genetics should be primary. For embryologists, however, developmental biology was a collection of problems. Genetics was only one approach of many. When one looks 
at the roster of speakers at the first Growth Society meetings in 1939, one is impressed by the different perspectives represented. ${ }^{20}$ Warren Lewis discussed tissue culture techniques, J. Needham spoke on the biochemistry of the organizer, Oscar Schotte's talk dealt with regeneration, and E. W. Sinnott presented material on plant morphogenesis. Papers by P. W. Gregory and Otto Glaser concerned growth and size relationships, while papers by Curt Stern and C. H. Waddington separately discussed the role of genes in development. There was even a philosopher, J. H. Woodger, to close the session.

The embryologists celebrated this heterogeneity. Berrill was delighted that "representatives of the field[s] of agriculture, bacteriology, biochemistry, biophysics, botany, cytology, embryology, endocrinology, genetics, histology, mathematics, pathology, philosophy, physiology, and zoology concentrated on a single issue, and considerable correlation and conceptual integration was accomplished." ${ }^{21}$ The single issue was, of course, development, and the listing of subjects was pluralistically alphabetical.

The American embryologists saw embryology and genetics as two intersecting spheres, one representing embryology, gene expression, phenotype, and the cytoplasm, and the other representing genetics, gene transmission, genotype, and the nucleus. However, the geneticists (who had originally established those boundaries) were beginning to see the spheres as enclosing the same domains, and genetics and embryology as simply two approaches to the same subject. Moreover, they believed that the genetic approach was superior to any other. As long as the geneticists confined their activities to those within the nucleus, the embryologists felt secure. It was only when the geneticists sought to cross the nuclear envelope into the cytoplasm that the embryologists became worried.

In Europe, the boundary of the nuclear membrane had never been formalized. The German school of genetics, never greatly interested in the gene localization program of Morgan's school, had been focusing since the early 1920s on the physiology of gene expression. However, as Harwood has shown, the German geneticists were split between those who accorded the nuclear genome absolute authority over cellular functions (a theory called Kernmonopol by its detractors) and those scientists who saw the cytoplasm as having an equal, if complementary, role in directing development. The advocates of Kernmonopol referred to the supremacy (Überlegenheit) of the nucleus and its dominating role (dominierende Rolle) in development. As one such advocate warned, if the cytoplasm contained hereditary determinants, "then the gene would be dethroned (beherrschenden Platz entthront) from its position of controlling development and evolution and would be forced to assume a secondary role." 22

During the 1920s and 1930s, however, many geneticists, such as Correns, von Wettstein, and Kühn, criticized this notion, claiming that the structure of the cytoplasm carried genetic potentials as well. In an analogy that would 
be extended by both von Wettstein and Just, the geneticist $H$. Nachtsheim noted that "the plasma is the building material (Baumaterial) for the chromosomes" and that the type of chromosome could be influenced by the type of cytoplasm contained in the cell. ${ }^{23}$ Although the center stage of genetics and development was occupied by English-speaking scientists, the German controversies remained very important, for both Just and Goldschmidt grounded their respective theories in this soil. As in America, there appeared to be little discussion in Germany between the embryologists and the geneticists. ${ }^{24}$ However, in Europe, the embryologists were paramount, and the geneticists were the ones struggling to make inroads.

In America, genetics had been remarkably successful and was starting to enter where the Europeans had long been theorizing, into the realm of gene expression. Here, the boundaries had been firmly demarcated. "The cytoplasm may be ignored genetically," Morgan had declared in 1926; but just as Morgan had chased his embryological problems into the nucleus, so the geneticists were chasing their problems right back into the cytoplasm. ${ }^{25}$ In so doing, the geneticists laid claim to embryology.

In any union or reunion of disciplines, the problem of professional hierarchy becomes acute. If the geneticists were content to study the stable nuclear genotype and the embryologists were satisfied to study the emergence of the changing cytoplasmic phenotype, all would be well. Each field could develop (or evolve) on its own. However, if the subject matter of embryology and genetics was actually the same (as in a resynthesis of the two fields), who was best suited to study such a united field, the geneticists or the embryologists? The relationship between the nucleus and the cytoplasm became critical in these discussions because of an implicit analogy: Genetics is to embryology as the nucleus is to the cytoplasm. If the nucleus were seen to control the cytoplasmic phenotype, then the geneticists would have the right to guide the field. Conversely, if the potentials for development were cytoplasmically located, the nucleus (and the geneticists) would play a subservient role. Given the boldly assertive nature of the newly organized geneticists, the embryologists, not surprisingly, tried to show that the fields were not coextensive, whereas the geneticists pushed for a synthesis. The implicit professional analogy between nucleus and cytoplasm should be remembered whenever such syntheses are being proposed, for the nucleus and cytoplasm became code words for genetics and embryology, respectively.

By 1938, genetics and embryology remained separate disciplines. While the geneticists were formulating a genetic approach to development, embryologists persisted in ignoring new ideas in genetics. Thus, Spemann's enormously influential book Embryonic Development and Induction (1938) completely ignored all of genetics. His only acknowledgment of the significance of the nucleus was his notion that nuclear transplantation experiments might show whether Weismann's view of nuclear determination was correct. ${ }^{26}$ 
Similarly, Paul Weiss's important embryology textbook Principles of Development relegated genetics to a single footnote saying that Curt Stern had seen "striking correlations between chromosomal aberrations and the morphology of the mutant cells [which] indicate a nuclear foundation of differentiation potencies." 27

The remainder of this essay will study two syntheses of embryology and genetics that were published in 1938 and 1940. These attempts at reunion, published respectively by geneticist Richard Benedict Goldschmidt (1878-1958) and embryologist Ernest Everett Just (1883-1941) were also attempts to reunite (or subjugate) American genetics into the matrix of German biology. They represented the two poles of continental thinking on genetics and embryology. In rejecting this reintegration, American biology demonstrated its independence from Europe.

\section{The Outsiders: R. B. Goldschmidt and E. E. Just}

In America in 1938, the breach between embryology and genetics had not been healed, and not everybody sought such a reunion. Yet in the next two years, four major volumes attempted a reunion of the two disciplines. Two books, authored by E. E. Just and Richard B. Goldschmidt, were considered as mature statements of their respective authors. Goldschmidt's Physiological Genetics sought to subsume development into a large framework of genetics. Indeed, development was seen as the epiphenomenon of activities directed by nuclear genes. Just's The Biology of the Cell Surface belittled the role of the genes, giving them minor roles to play in the essentially cytoplasmic process of development.

In 1938 both Just and Goldschmidt were in similar positions. Both were cultured, sophisticated, and arrogantly proud men who had been exiled from their homelands and from their disciplines. Goldschmidt was a German citizen of Jewish descent working in America because of the genocidal policies of the Third Reich. Just, conversely, was a black American who felt forced to work in Europe because of racial discrimination in American universities.

By 1938, Goldschmidt had already alienated himself from the majority of geneticists with a series of increasingly serious breaks with the genetic "orthodoxy" of the Morgan School. First, Goldschmidt had disagreed with the simple chromosomal genetics of sex determination espoused by Morgan, Bridges, and Sturtevant, preferring instead the physiological approach of the German school that he had helped lead. Reflecting on his lectures at Woods Hole in 1915, Goldschmidt wrote that only Jacques Loeb, a physiologist, "understood the significance of my work in trying to bring dynamic viewpoints into genetics." ${ }^{28}$

Second, Goldschmidt denigrated the basis of the grand synthesis of ge- 
netics and evolution into neo-Darwinism. (He later claimed that he was a neo-Darwinian before neo-Darwinism and saw its flaws as the others were adopting it.) Crucial to this synthesis was the belief that the gradual accumulation of small mutations led to distinct species. There was no qualitative difference in the genetic mechanisms that produce races, species, or higher taxa. However, by the mid-1930s, Goldschmidt was claiming that microevolution (the evolutionary changes within species) and macroevolution (the origin of divergent species and higher taxa) were caused by different mechanisms. The synthesis of Mendelism and Darwinism could explain microevolution, but the current genetic theories could not explain the creation of new species. He now suggested that species differences might arise either by "macromutations" involving chromosome structure or by regulatory mutations early in development-processes very different from the structural gene mutations then known by geneticists. To make matters more difficult for himself, he grouped natural selection and special creation together as "extreme suppositions," neither of which contains the whole truth..$^{29}$

Third, Goldschmidt disagreed with the very corpuscular nature of the gene itself. He interpreted the recent papers of J. Schultz, B. Glass, and N. P. Dubinin as indicating that the presence of a portion of the chromosome did not determine whether or not it is optimally active. Rather its position within the chromosomal complex determined its activity. This position-effect phenomenon could not be explained by classical genetics and allowed Goldschmidt to postulate "a theory of the germ plasm in which the individual genes as separate units will no longer exist." ${ }^{30}$ Moreover, whereas most of his colleagues were interested in the transmission of hereditary factors, Goldschmidt concentrated on their expression.

Goldschmidt had indeed "struck a hornets' nest" in the United States. The Neo-Darwinians' counterattack succeeded in burying his work for nearly fifty years. Gould has reported on the depth of this neglect, stating that Goldschmidt "suffered the worst fate of all: to be ridiculed and unread." ${ }^{31}$ Elsewhere, Gould has compared Goldschmidt to Orwell's Goldstein, the object of the daily two-minute hate sessions in $1984 .{ }^{32}$ Certainly by 1938 , Goldschmidt was an outsider both to his field and to his country.

Goldschmidt was, in one important sense, much more fortunate than Just. Neither of them could aspire to the heights of the career they had entered. Goldschmidt made most of his reputation while working as Richard Hertwig's assistant, and he could never hope to get a tenured position in a university even though he essentially ran Hertwig's laboratory and taught Hertwig's courses. "A number of times my name had been in the running, but in every case academic anti-Semitism had decided against me. Thus I longed to get away from the university into a pure research position. But there was none in Germany, and $I$ had to resign myself." ${ }^{33}$ Goldschmidt was not wrong in his assessment, as T. J. Horder and P. J. Weindling have shown ${ }^{34}$ In 1914 
Theodor Boveri, the premier cytologist in Europe, wrote to his former student, Hans Spemann, telling him he disliked Goldschmidt's face and he did not want yet another Jew to become a director of a Kaiser-Wilhelm Institute. However, when the Kaiser-Wilhelm Institute for Biology was founded in Berlin, the president of the Kaiser-Wilhelm Society, theologian Adolf Harnack, made it clear that religion would not play a role in the selection of the department directors. Thus, Goldschmidt escaped the Prussian university system to become a division director of the Kaiser-Wilhelm Institute for Biology in 1913.

Just's appointment to Howard University was not an escape from the throes of American racial antagonisms. As Kenneth Manning has shown in his excellent biography of Just, Howard University abused their star biologist. ${ }^{35}$ Just was graduated from Dartmouth College with honors in both biology and English. Howard was the only place in the country where a black scientist had a chance to rise to any position of responsibility and power, and Just reached this "height" as soon as he left college. After that, the administration of Howard withheld funds that Just had raised, gave him enormous teaching assignments, and made certain that he could not go anywhere else. By working at Woods Hole and University of Chicago, Just received his doctorate under Frank Lillie; but still, there was no other place in America where Just could pursue his work. Earlier, Just had gone to Dohrn's Stazione Zoologica in Naples, and in 1930 he decided to leave America permanently. His work on fertilization and parthenogenesis in marine organisms was appreciated more in Europe than in America, and he was unable to get funds to continue his work in his native land. Unfortunately, Just's timing could not have been worse, for Mussolini was in the process of nationalizing the scientific enterprises in Italy, and Just was interned briefly as an enemy alien. The Biology of the Cell Surface, the culmination of Just's biological theories, was written in Paris, away from both homes, America and Italy. Just's work, like that of Goldschmidt's, met with polite neglect. Although his 1931 paper in Naturwissenschaften $^{36}$ had provided the first evidence for functional changes in the cell surface during development, it was all but ignored, and even when cited (as in Heilbrun's books), it was not discussed. When research on the cell surface began again after World War II, Just's work was quickly forgotten. ${ }^{37}$

Manning's biography of Just chronicles the hardships that a competent black American scientist met in securing employment, respect, and funds during the first half of this century. Yet one of the best expressions of the outsider's education comes from Goldschmidt, himself, and probably holds equally true for the sensitive, self-confident black American scientist.

I think, actually, that nobody has a better chance to see the ugly side of human nature than an intellectual Jew who has succeeded in life. Thinking of the innumerable instances when I was stabbed in the back by those who 
breathed deference in my face, fellows intellectually and morally below me, I am surprised that I am not a pessimist. No doubt, this thorn in my flesh has had an immense influence in shaping my character. It has made me cautious and remote, unwilling to show the warmth of my nature unless I know the other man thoroughly. It has taught me to look through people and to analyze them. It has forced me to learn to control my temper, to appear quiet on the surface when I am burning, to appear distant when I long for friendship, to develop self-observation and self-control to a perfection-all of which is frequently misinterpreted as coolness or haughtiness. It has also produced an unnecessarily deep contempt for the second-rater, the go-getter, the social peacock, and clubman. And it certainly killed a number of qualities that I otherwise would have developed, qualities I consciously forced into the background because I knew that their development would expose me to slights and hatred that my soul was not sufficiently robust to drop off lightly. What is the use of aspiring to leadership of men if every half-wit, scoundrel, or Philistine can knock you out with the single word 'Jew'?

Just was never fully accepted by the American embryological community (and, as Pauly shows in this volume, at Woods Hole, it was indeed a community), and he burned his bridges to America when, in 1930, he walked out of the Marine Biological Laboratory's (MBL) tribute to Lillie, saying that he had known more collegiality during one year in Europe than during all his time at the MBL. ${ }^{39}$

But Just was an outsider to embryology for other reasons as well. His contemporaries did not think his research was important, and experimental embryology had left Just behind. The heated debates between Loeb and Lillie over fertilization had all but been forgotten in the 1930s. Textbooks paid no account to what had been a dramatic struggle twenty years before. There was enormous excitement in embryology, and this excitement had moved from fertilization to embryonic determination. This was the era of the great transplantations. By reciprocal transplantation Spemann had demonstrated the importance of gastrulation in determining embryonic cell fate, and he and Hilde Mangold capped those experiments by showing the existence of the "primary embryonic organizer." Hörstadius recombined different tiers of sea urchin blastomeres to discover gradients of preformed substances that informed those cells how to develop, and Harrison transplanted salamander limbs in different positions to discover the laws by which organisms retained their polarity. Niu, Twitty, and Willier (the last mentioned having begun his graduate work under Lillie in the same year Just received his doctorate) discovered the ways in which neural crest cells migrate and differentiate, and Weiss investigated the ways in which neurons migrate to their target tissue. A new research program had been established, one that Joseph Needham has christened "Gestaltungsgesetze, the rules of morphological order." 40 
Whereas neither Lillie nor Loeb was working on fertilization after 1920 , Just continued studying these same problems of fertilization and was still using the older, less invasive techniques. His work and his methods, though still scientifically valid, had "gone out of fashion." Why was this the case?

Just's retention of old methods and problems has many explanations. One explanation focuses on his professional responsibilities. ${ }^{41}$ Other investigators at Woods Hole often had two research interests, one that they pursued during the summer (when the embryos abounded at the MBL) and another that they pursued during the school year while landlocked and cold. Due to his teaching responsibilities, Just could pursue research only in the summer and was denied the chances to work on other lines of inquiry. Similarly, other investigators had a regular influx of graduate students, who could stimulate new research ideas and keep their advisors up to date. Just had neither collaborators nor a flow of new graduate students to spur him into newer areas. Another explanation is that Just's research plan was still a viable part of European, if not American, biology. Starting in 1930, many of Just's papers were sent to German journals, such as Protoplasma, that were more sympathetic to the role of cytoplasmic factors in development.

There are other explanations, too. Just was a perfectionist who did not like to leave a problem unsolved. The importance of the cortical cytoplasm during fertilization had been suggested by Lillie and documented by Just. Just did not want to leave the field until he had established incontrovertible proof that this was the case. Also, Just felt a respect and sense of loyalty to Lillie. He had cast himself as Lillie's "bulldog" against Loeb, and he was fighting his mentor's cause. There may still be another reason. As we shall see, Just "identified" himself with the cortical cytoplasm. Most biologists conceived of the cytoplasm as being dominated by the nucleus and merely responsive to its demands. The cortical cytoplasm was ignored by almost every biologist, some of whom thought that it was not even a living part of the cell. It was indeed ignored by embryologists and spurned by geneticists. To Just, the cortical cytoplasm was the most exciting part of the cell, guiding all intercellular communication, controlling cell functions, regulating early development, and serving as the vanguard of animal evolution. The nervous system of humanity, he claimed, was derived from the cortical cytoplasm. As I will try to show hereafter, Just was to fight the benign neglect of the cell periphery. Just identified with the cause of the cortical cytoplasm and in fighting its cause was fighting his own. Just's use of the cell as a model of society will become explicit in this essay.

Thus, these two syntheses of embryology and genetics, published in the late 1930 s, were both written at a time when their respective authors were living in exile from their homeland and scientific communities. Yet two books having the same synthetic goal could hardly be more different. There is but one reference (Lillie's 1927 paper wherein he despairs of synthesis) in com- 
mon between the two books. Just's book concentrates on those embryological phenomena manifested by cytoplasmic changes during the early development of marine invertebrates, whereas Goldschmidt's volume focuses on those later stages of insect development that he can prove to be under genetic control. As Just had said earlier, he was himself more interested in the back than the bristles on the back. Goldschmidt, however, delighted in bristles and wing hairs, and felt that they were just as much a product of development as any other structure. ${ }^{42}$

The Biology of the Cell Surface and Physiological Genetics are intensely personal books, each reflecting the idiosyncratic positions of its respective author. ${ }^{43}$ Just and Goldschmidt used their books to promote a view of development at odds with those of their peers, and in doing so, each man quoted nearly his entire scientific corpus. Both represent attempts of two highly original scientists to integrate what they considered to be the important data on the awesome problem of how an organism is constructed from a fertilized egg. Both seek to place American genetics into the German type of developmental physiology. I propose to discuss these two books on three levels: first, as straight scientific texts (as their respective authors no doubt intended them to be read); second, as professional texts involving partisan claim-staking by two rival professional groups both seeking to study the same phenomenon; and third, as political texts, inasmuch as there is an implicit metaphor between the proper nuclear regulation during development and the proper action of a central governing body in a society. The relationship of the nucleus to the cytoplasm established in the scientific text becomes the way in which the relationship of genetics to embryology is seen in the professional text and the relationship that a central government bears to its people in the political text.

\section{The Cellular Federalism of E. E. Just}

The Biology of the Cell Surface was an attack on the mechanistic and reductionist view of development promulgated by the geneticists on the one hand and the biochemists on the other. Just's work attempted to accomplish two tasks thought to be mutually exclusive. First, it sought to counter the genetic mechanistic view with a cellular holism. To this end, Just redefined the scientific vocabulary used to describe developmental phenomena and elevated the cytoplasm at the expense of the nucleus. Second, it tried to integrate genetics and embryology, as both the nucleus and the cytoplasm played necessary roles in cell differentiation. In this synthesis, Just posited that all the potentials for development were present in the cytoplasm, and gave the nucleus a necessary, but secondary function.

Just began his book with a seventy-four page defense of cellular holism against the reductionist research programs of the geneticists and biochemists 
of the 1930s. His view of the cell as the irreducible unit of life was expressed on the title page in a verse from Goethe containing a remarkably apt pun.

Natur hat weder Kern

Noch Schale,

Alles ist sie mit einemmale. ${ }^{44}$

The noun Kern, translated here as kernel (inasmuch as Goethe's analogy is that of a fruit), also possesses the cytological meaning of cell nucleus. This unity of the cell was to be the hallmark of Just's book. Therefore, he attacked the radical separation of nucleus from cytoplasm and the supposed hegemony of the nucleus over the other regions of the cell.

In general, the organization of living matter, that is, of protoplasm, appears as consisting of two components, a nuclear and a cytoplasmic. Although most often these are set off as two distinct regions, as a sphere (nucleus) within a sphere (cytoplasm), this sharp differentiation is not invariable. For several reasons, as will be shown beyond, much of modern biological investigation has centered upon the nuclear component as though it were indeed the kernel of life. Not only has the cytoplasmic component been relatively neglected but also have those protoplasmic systems which lack sharply defined and set-off nuclei received scant attention. . . Because of the rapid rise of genetics, hegemony in the protoplasmic organization has been ascribed to the chromosomal structure of the nucleus and the cytoplasm has been subordinated as though it be a mere protective and nutritive shell. It is no part of the purpose of this book to minimize the achievements of genetics and the investigations on chromosome-structure, all outgrowths of descriptive studies on protoplasmic organization. Instead, inasmuch as life, as we know it so far, resides in the whole system, the pages which follow aim to show how far life-processes are related to the dual and reciprocal components, nuclear and cytoplasmic structure. ${ }^{45}$

Just's critique of genetics was similar to that of other embryologists such as Harrison and Lillie. He was willing to accept the chromosomal theory of inheritance but could not see the unchanging chromosomes directing embryogenesis. First, he did not see how a chemical gene could persist intact throughout numerous cell divisions. Having no concept of molecular replication in his mind, he supposed that if a gene were a molecule controlling development, it must become half a molecule after the first cell division and a quarter-molecule after the second cleavage. Second, he followed Lillie and Harrison in asking: "How could genes be responsible for differentiation, if they are the same in every cell?" Not averse to using ridicule, Just chided geneticists such as Demerec who had recently spoken on the embryologist's home turf, Woods Hole: "Untutored savage man made his god as big as pos- 
sible because his god could do everything. It remained for the geneticists to make one of molecular size, the gene. Here obviously infinite minuteness means infinite capacity. According to one geneticist Demerec, the gene has almost magic power. Here is physico-chemical biology with a vengeance." 46

Having disposed of the genetic theory of development, Just elevated the roles of the cytoplasm. He did this in two approaches. First, he redefined the terms of cell biology, which he thought had been warped by genetics. Second, he summarized the scientific evidence for the importance of the cytoplasm for developmental regulation. Just was extremely concerned with the precision of the scientific language, and of the sociological function of language. He alluded to the relationship between language and professionalization, saying that the last thirty years had seen genetics "develop almost to the proportions of a separate science - at least it has a very rich vocabulary of its own." In his next paragraph, Just would use his own rhetorical devices to exclude geneticists not only from embryology, but from the entire science. Here, he contrasted geneticists who accepted the gene theory of development with "biologists, on the other hand," who harbored doubts. ${ }^{47}$

The Biology of the Cell Surface is full of carefully phrased redefinitions. Just redefined such terms as cytoplasm, cell membrane, life, fertilization, and cell division in a context of embryological holism and against genetic reductionism. For instance, he described in detail the events of fertilization in four species of marine invertebrates to demonstrate that "the fertilization-process in these four examples resolves itself into two phases-an external, that concerns the ectoplasm, and an internal, that concerns the nuclei." After demonstrating that the binding of sperm and egg is a complete, well-orchestrated phenomenon involving adjacent cell surfaces and that in some experimental (parthenogenesis) and natural (Rhabditis) instances, fertilization occurs without nuclear fusion, Just concluded: "To retain the old definition of fertilization as the union of egg and sperm-nucleus is to violate both fact and logic." Similarly, Just found that "common usage has been loose in giving the term, cell division, the meaning of the division of the nucleus." After demonstrating numerous cases where cells divide without mitotic figures and where nuclei divide without cell division (as in early insect eggs), he stated, "It becomes obvious in the light of what has been said that nuclear and cytoplasmic division are separate phenomena. . . Cell division is to be defined as the division of the cell body. . . Finding it impossible to relate division of the cytoplasmic mass to the nucleus, we turn to the cytoplasm itself." 48

As firm as Just was against nuclear "hegemony," he was equally hard on those who he thought misrepresented the cytoplasm. Foremost among these malefactors were the biochemists who sought to explain embryogenesis by breaking embryos apart and measuring chemical reactions. Needham's epic Biochemical Embryology had just been published in 1931, complete with a magisterial historical prologue giving the new biochemical methodology a 
classical pedigree. Just belittled those activities and, in a metaphor linking biochemistry with colonialism, depicted biochemists as conducting "punitive expeditions against the egg." Moreover, Just was adamant against using life as a means and not an end in itself. "The cell is never a tool. . . Living matter is never an excuse and living phenomena never an opportunity for the display of the investigator's physico-chemical knowledge." 49

Just sought the mystery of life, not its mastery. ${ }^{50}$ This attitude was more akin to the naturalist than to the experimental embryologist of the 1930s. Indeed, Just's approach was very much that of the naturalist, making detailed observations without perturbing his organisms experimentally. Throughout The Biology of the Cell Surface, he criticized those modern researchers who experimented on organisms that are already damaged and who manipulated them so harshly that no value could be attached to their results. This lack of care, he believed, was due to a lack of respect for living phenomena. "Scientists degrade eggs by calling them "material.' They do not respect their specimen, nor do they respect the integrity of life." Rather, "those experiments which alter a normal process the least have today especially great value in the study of the egg and its development. . . . By experiment we here slightly exaggerate, there lightly fret the tones out of which the harmony of the living state arises." ${ }^{51}$ This approach is a far cry from the major embryological research program of the 1930s, which was characterized as dissecting the whole into smaller and smaller parts "quite heedless as to how far analysis into the nonvital may be possible." 52

This brings us to the main thrust of Just's book, his experiments showing the importance of the cell cortex in development. Just began his analysis of the cell surface with a review of fertilization. What interested Just was not the movements of the nuclei or even the rearrangements of the cytoplasm that are so evident during fertilization, but the immediate effects brought about by the attachment of sperm and egg. To Just, all the other effects are secondary to the real drama that was occurring at the egg cell surface. To observe these events, some of which take place in a matter of seconds, requires persistent and careful observation of the most perfectly normal eggs. If the eggs were damaged, any conclusions that might be drawn from them were useless, and an observer who was not careful and persistent would likely dismiss the small transient events as meaningless.

Just's first paper, in 1912, established his reputation as a meticulous observer of natural phenomena. Here, Just demonstrated that the plane of the first cleavage of Nereis eggs is determined by the point of sperm entry. ${ }^{53}$ This observation implied that the particular point of the cell surface that bound the sperm played a decisive role in the future development of the organism. For the next eight years, Just focused his research on detailed observations of the fertilization reaction in marine organisms. In 1915, he published another paper on the fertilization reaction of Nereis, which supported the work of his men- 
tor, Frank Lillie, against that of Loeb. The debate between Lillie and Loeb over the nature of fertilization had been heated for several years, and Just's research added more strength to Lillie's model. What is striking in the rhetoric of this 1915 report is that Just supported his case by using Loeb's own words against their original author. ${ }^{54}$ Just's literary technique is in marked contrast to the style of Lillie's own paper (published next to Just's in the same volume), which is a detailed rebuttal of Loeb couched in the most polite and carefully phrased language. It is no mystery why Loeb (and his students) developed an antagonism to this brash newcomer to their field. ${ }^{55}$

Unlike most researchers of his era, Just held that "fertilization is essentially a process of the egg." The sperm was secondary and, in some species, eliminated. Just's major support for this view came in 1919 when he published two papers on sea urchin fertilization. In the first paper, he dissected the initial minute of fertilization into a series of reactions on the egg surface. First, the sperm did not bore its way into the egg; rather the egg pulled it in. About ten seconds thereafter, a blister formed at the point of sperm entry. Droplets dispersed from this point, and the membrane that had been glued to the egg surface began to peel off. Moreover, "before the actual elevation of the membrane, some cortical change beginning at the point of sperm entry sweeps over the egg immunizing it to other sperms; the direct opposite pole of the site of sperm entry is the last point affected." This cortical change precedes the actual beginning of membrane lifting, because "before the membrane begins lifting at the site of sperm entry, sperm can no longer enter at any point of the egg." Only afterwards does one see the formation of the fertilization membrane, starting at the point of sperm entry. Just had observed what are now referred to as the fast and slow blocks to polyspermy, and he interpreted them as such. His interpretation is particularly significant in that he repeated the assertion that "the membrane is merely the sign and consequence of more profound cortical changes." 56

In the second paper of 1919, Just gave support to Lillie's fertilizin hypothesis by showing that the ability of sea urchin eggs in the water to agglutinate sperm (presumably by fertilizin) correlated with the fertilizability of the eggs. This fertilizin theory was important to Just because one of the bases of Lillie's model was that "fertilizin is located in the cortex of the egg." ${ }^{57}$ These two papers of 1919 give the impression that Just championed the cortex even more than he championed fertilizin. The fertilizin model was worthwhile solely because it showed the importance of the cortical cytoplasm, and not the converse.

From this point until 1931, Just played many variations on this same theme, stressing the responsiveness of the cortical cytoplasm. He could readily turn a research report into a polemic, and did so in 1929, in reply to a series of investigations by R. Chambers. After questioning the validity of Chambers's data by showing how he had used improperly prepared eggs, Just gave 
his own description of the minute, delicate filaments in the cortical cytoplasm of echinoderm eggs. Just then passed from data to propaganda.

The reactivity of the cell as a whole-its individual and peculiar response to stimulation with attendant measurable physical and chemical changesis largely, if indeed not wholly, a cortical (ectoplasmic) phenomenon. Cortical changes in ova are, therefore, no mere epiphenomena: they constitute the sine qua non of cellular life. In responding to and propagating the effects of the initial event in the fertilization-reaction, the attachment of the spermatozoon, the egg exhibits cortical changes which eventually modify the whole protoplasm and direct the course of ontogeny. ${ }^{58}$

In The Biology of the Cell Surface, Just referred to these strands in an important statement where various metaphors of the cell cortex (ectoplasm) are contrasted.

All these considerations and data indicate that the surface-cytoplasm cannot be thought of as inert or apart from the living cell-substance. The ectoplasm is more than a barrier to stem the rising tide within the active cell-substance; it is more than a dam against the outside world. It is a living mobile part of the cell. It reacts upon and with the inner substance and in turn the inner substance reacts upon and with it. It is not only a series of mouths, gateways. The waves of protoplasmic activity rise to heights and shape the surface anew. Without, the environment plays upon the ectoplasm and its delicate filaments as a player upon the strings of a harp, giving them new forms and calling forth new melodies. But these are too nice for the undiscriminating ear of man. ${ }^{59}$

For Just, the sperm triggered the egg to develop but did not play a major role afterwards. It was merely the finger that plucked a well-tuned string to call forth a resonance. This idea is also expressed in his analysis of Kruger's observation that in the Rhabditis egg the sperm activated the egg to develop but remained inert afterwards, never uniting with the egg nucleus. That sperm was not essential for development was further shown by parthenogenesis, in which development is initiated by artificial means. The analysis of artificial parthenogenesis was a major thrust of Just's research program from 1919 to 1930 , as it enabled him to look specifically at the cortical cytoplasm reaction system that began development. Just saw a "rhythmical movement of water" causing regional dehydration in portions of the egg and concluded that the sperm or parthenogenetic agents first caused a dehydration of the cortex, which subsequently dehydrated the cytoplasmic ground substance, which thereby brought about mitosis. It is this reallocation of cortical water that he believed brought about development.

When parthenogenetic agents displaced water from the cortex, development ensued. Just discovered that one of the agents capable of causing this 
response was ultraviolet irradiation. As early as 1926 , Just had observed that Nereis eggs exposed to ultraviolet light developed abnormally. Moreover, many of these abnormal embryos showed a localized defect, "which is traced back to the site of cortical injury by radiation." ${ }^{60}$ It is not surprising, then, that as late as 1932 Just thought he had turned the tables on the geneticists, dismissing radiation-induced mutations as mere epiphenomena of the real site of injury - the cell cortex. "Normal chromosome distribution and combinations depend upon the integrity of the cortex; their aberrant behavior is the effect of the loss of this integrity. . . This would mean, therefore, that chromosome-behavior is not a primary one, but rather the expression of the ectoplasmic reactions." 61

Thus, Just contended that mutations were the result of cortical disruption and not of direct injury to chromatin. This concept is extremely important, for it shows that for Just, genetics was subservient to development (or similarly, that the nucleus is subservient to the cytoplasm). A mutation is not a defect in a gene, but a defect in the cortical cytoplasm that directs development. Starting at this point, Just could speculate as to how genetics and embryology are related. His first such speculations are in this article analyzing mutation. He returned to Boveri's original experiments on dispermic eggs, "as a possible starting-point from which we may begin an attempt at the union, nowadays seemingly hopeless, of genetics and the physiology of development." Just interpreted Boveri's data to show that the aberrant chromosomal arrangements were possible only because of the "weakened conditions in the cytoplasm which make dispermy possible." After this, Just put forth his view (hearkening back to Driesch) that the cell is a system wherein nucleus and cytoplasm reciprocally interact with one another." 62

Just believed that the nucleus and its chromosomes are normal cellular structures that are constructed de novo from cytoplasmic stuff after each mitosis. But Just claimed that some relationship clearly had to exist between genetics and embryology "since heredity is expressed during the process of development." Because the geneticists had failed to unite the two, a new theory was required. Just's theory is an inverted Weismannism wherein all the hereditary potentials for development exist in the cytoplasm of the fertilized egg. However, these potencies are all in an inhibited state. The nucleus exists to absorb these inhibitors from the cytoplasm differently in each cell. "Genetic restriction then depends upon the removal by the nucleus of certain materials from the cytoplasm, leaving others free. The free materials determine the character of the cell. . . . With each cleavage each nucleus fixes all material other than that which makes the blastomere what it is. The potencies for embryo-formation are all present in the uncleaved egg." 63

There is a genetically based progressive restriction in potency as the nuclear chromosomes absorb the various agents of differentiation. "Thus, finally, every cell in the most complex organism has in its nucleus all the 
potencies except that one in the cytoplasm that makes the cell specific." In the germ cells, these potencies would be released by the chromosomes. In an extremely important statement, Just declared, "Every cell in an organism becomes what it is because its cytoplasm has free its particular potencies whilst the nucleus binds all others. These latter would, if left unbound in the cytoplasm, act as obstacles to the display of special potencies." ${ }^{64}$

The chromosomes are constructed of the unused substances that would have caused the cell to differentiate in another fashion. For Just, the nucleus was not the throne room of the cell; it was its refuse dump, a necessary, but far from noble, position.

Science is a creative human product, and scientific writings, like music, art, and literature, are historical artifacts. Looking at Just's scientific work in its historical context allows us to see two hidden agenda contained therein. The first concerns the relationship between embryology and genetics. Just viewed "differentiation and heredity as merely two expressions of development." "6s Genetics was thought to be subservient to embryology, just as the nucleus was seen to be formed from and be subservient to the potencies of the cytoplasm. In Just's model, the cytoplasm is where the answer to heredity and differentiation is to be found, not in the nucleus. In this newly synthesized field, the embryologists travel the straight and noble path.

Another hidden agendum concerns government. The developing organism is a polity of interacting cells, and each cell contains a nucleus and cytoplasm. The way that Just expressed the genetic regulation between these cellular elements is fascinating. In effect, Just postulated a noble cytoplasmic populace that contained all the potencies needed for the body or body politic. The nucleus acted to withdraw certain "obstacles" from the cytoplasm such that a specific potential could be expressed. In another cell, this obstacle is itself a specific potential. Thus, the nucleus, the central government of the cell, allows the expression of cytoplasmic potential by suppressing other possible potentials. This view reflects a specific solution to a problem that was being debated at that time by black scholars. The 1930s was the era of black migration from the South to the North and of the ensuing ethnic battles in the cities they entered. (In 1935, the Herald Tribune claimed that a second ItaloEthiopian War was being fought in the streets of New York City.) It was the era of Langston Hughes and Richard Wright. Blacks had their potentials, too, but could only express them if other potentials/obstacles were removed. The Harlem Renaissance before the Depression showed how great those potentials could be when realized. The use by Just of the word "obstacle" instead of the more technical word "inhibitor" is instructive. The embryo-that ideal of organization--is modeled like an ideal society, a society that allows the optimal expression of its constituents' potentials. Just never enjoyed political debates; they bored him. Perhaps he already had an ideal society in mind and was trying desperately to bring that idea before the public. This ideal of government was his cellular republic, and Just explicitly viewed the egg cell as a micro- 
cosm. Just knew that people tend to extrapolate from nature to politics, and he felt that Kropotkin's mutual-aid hypothesis of evolution was a valid extrapolation of nature into human behavior. Moreover, "the means of cooperation and adjustment is the ectoplasm," because the ectoplasmic cortex of the egg is incorporated into the nervous system of adult vertebrates. ${ }^{66}$ For Just, the agent of evolution was not the nucleus, but the cortical cytoplasm, the marginalized populace. Just viewed the cell and the embryo as perfectly balanced societies. Within an embryo, each cell had a defined role. The type of cell it became was determined by the cytoplasmic potentials remaining after the others were locked away in the nucleus. All potentials were needed in a balanced social or physical organism.

Just's federalism of the cell was a rebellion against contemporary views of the Zellenstaat, which were more authoritarian, and was the cytological analogue of the "physiological democracy" of his friend W. C. Allee ${ }^{67}$ In viewing the embryo as a society where each cell is allowed to develop a particular potential, Just saw a model of a society where each group of people could express its potential once certain "obstacles" were removed. It was a federalism that allowed the minorities to express themselves in a local fashion and, at the same time, contribute to the general welfare of the society. This was precisely the urgent political question that was being addressed by the leading black sociologists of Just's time. W. E. B. DuBois called it the problem of the majority. "Granted that government should be based on the consent of the governed, does the consent of a majority at any particular time adequately express the consent of all? Has the minority, even though a small and unpopular and unfashionable minority, no right to respectful consideration?" 68

Indeed, DuBois inadvertently used an embryological metaphor when he demanded that the majority must not crush the self-development of a minority population. The goal of the American Negro, said DuBois, is "to be a coworker in the kingdom of culture, to escape both death and isolation, to husband and use his best powers and latent genius." ${ }^{69}$ This was precisely the dialectic that the embryo had solved, groups of cells achieving self-development, expressing their unique potential to the betterment of the organism. But there was another, deeper parallel; for the cell itself had a government. The embryo was a federal republic of its constituent cells, and each of the cells harbored the potentials (as embryologists knew from Driesch's work) of every other type of cell. According to Just, each embryonic cell was directed to create a nucleus from its cytoplasmic material. These materials were the agents that would express certain potentials, and they were inhibited from so doing by being kept in the nucleus. Only one set of potentials could be expressed in any cell. The nucleus did not give any orders to the cytoplasm. Rather, the order was coming from the entire embryo. As Driesch had shown, the community of cells together determined the fate of each individual cell. The cell was not ruled by the nucleus; for that matter, it was not ruled by the cytoplasm either. The cytoplasm was far more important than the nucleus, to be sure, as it con- 
tained the developmental potentials and reacted with other cells and with the external environment; but the total community of embryonic cells is what determined the fate of a particular cell.

The development of an organism is a history of its cellular interaction. Therefore, to Just, development was a property of the cytoplasm; for only the cytoplasm could respond. The most responsive part of the cytoplasm-as Just showed from fertilization studies - is the cell cortex, the outermost cytoplasmic rim. It is this peripheral rim of material that Just championed as the prime mover of development, evolution, and intelligence. Whereas the mainstream of cellular biologists believed and assumed that the cytoplasm took its instructions from the central nucleus, Just believed in the primacy of the cortex. I believe further that he made some psychological self-identification with the object of his meticulous observations. He thought the peripheral rim of cytoplasm beautiful, sensitive, creative, powerful, important, and disregarded. In short, his view of the cortex mirrored his view of the black in American society. As we will see later, the heroes of his book are both the cell surface and himself. By championing the cause of the cortex, he subtly championed his own. ${ }^{70}$

There is excellent scientific argument in the works of E. E. Just. But there is more. There is a professional polemic designed to prevent his profession from falling into the hands of geneticists, and there is a political model of a federal republic that would recognize the potentials of his race. The three agenda are never far apart, and each one informs the other. What is particularly fascinating is that the same mixture of science, professionalization, and cytopolitics is found in the work of Just's geneticist contemporary, Richard Goldschmidt.

\section{The Nuclear Aristocracy of Richard Goldschmidt}

Physiological Genetics (1938) was Goldschmidt's attempt to reduce embryology to a subset of genetics. On the very first page of this volume, he redefined heredity to include "the mechanism of heredity," which he called "static genetics," and the "problem of development" which he called "dynamic genetics." Proclaiming that "development is to be linked specifically with the function and action of the gene," he preferred to call the latter study "physiological genetics." This part of genetics, wrote Goldschmidt, "was practically banned from advanced treatises and textbooks of genetics, and the opinion has developed and has even been voiced that it is not worth while to mention a field in which nothing is known with certainty." Goldschmidt admitted that "we know next to nothing of the action of the heredity material in controlling development," but he continued that he would now "present the entire material available." 71 
Because Goldschmidt saw development as an epiphenomenon of gene activity, even the most complex patterns of embryonic ontogeny were seen as driven by genes. "Development is, of course, the orderly production of pattern, and therefore, after all, genes must control pattern." ${ }^{72}$ Goldschmidt assumed that if a problem is developmental, then it is in essence a genetic problem.

Goldschmidt then looked at the mechanisms by which the nucleus controlled development and offered two propositions-the first on the role of timing in gene activation and the second on the developmental inefficacy of the cytoplasm. The temporal basis of differentiation was one of the ideas that Goldschmidt tried in vain to get other geneticists to accept. Embryologists asked, "if all the genes in all the cell nuclei were the same, how can the genes control development?" Goldschmidt answered that the timing of gene activity was crucial. "The genes controlling pattern act by producing definite reactions of definite velocity." 73 Goldschmidt had analyzed a series of bizarre mutations called homoeotic mutants. Here, the development of a particular embryonic structure follows the development of another particular structure. For example, Drosophila having the dominant mutation Aristapedia have legs developing where their antennae should be. In some alleles of this locus, part of the antenna is converted into a leg structure (such as a tarsus or trochanter), whereas other alleles produce the entire transformation of antenna to leg. Goldschmidt analyzed these mutants and concluded that the aberrant development was not due to the elaboration of different materials by different genes, but to the aberrant timing of gene activity. "Here, then, a mutant gene changes an embryological process by shifting its initiation to a different point in time." Small changes in timing could create complex morphological changes. ${ }^{74}$

Goldschmidt looked at all genetic variations as changes in development. To him, the study of wing patterns or eye pigmentation was just as much a developmental problem as the development of the wing or eye themselvesand more readily analyzed. Like Just, Goldschmidt wanted to study these processes with the least possible perturbation. Goldschmidt saw the analysis of mutations as being superior in this respect to surgical manipulation.

But certain processes [of development] may be changed without deleterious consequences; and if this is done by genetic change, we call it a mutation. Such considerations, obvious as they may seem to be, make us expect that the action of the mutated genes upon development cannot be of a different type from any other changes of development induced by experimental agencies; in both cases, something changes the detailed course of some developmental processes.

As evidence of this, Goldschmidt brought forth his data on phenocopies, organisms where experimentally produced abnormalities mimic certain mu- 
tants of the untreated organism. He provided numerous examples of temperature altering the pigment pattern of one race of butterflies in such a way as to make it resemble that of another. By relating the timing of heat shocks to the developmental pattern and by correlating the timing of eye color formation in various mutations with the time at which that color first develops, Goldschmidt concluded that "the mutant gene produces its effect, the difference from the wild-type, by changing the rates of the partial processes of development." ${ }^{75} \mathrm{He}$ was to use this principle of timing not only to explain mutations, homoeosis, and phenocopies, but also morphogenetic patterns and embryonic induction. In all these instances, development is reduced to being an epiphenomenon of genetics.

But there was other evidence as well. In 1934, J. Hämmerling had published his remarkable observations upon the development of Acetabularia. ${ }^{76}$ These experiments (which Just ignored in his book) were critical in convincing biologists of the developmental importance of the nucleus. Hämmerling had shown that the nucleus of this unicellular protist controls the morphogenesis of its complex cap. Moreover, if the nucleus of one species were transplanted into a decapitated stem of another species, that stalk would regenerate a cap characteristic of the nuclear donor. To Goldschmidt, "this shows that actually the genes within the nucleus control the production of specific formative stuffs (not unspecific as in the hormonic type) which diffuses through the cytoplasm to the place of its form-controlling function." He saw this as "forging an interesting link between genetics and experimental embryology" and observed that it demonstrates "that such processes of distribution and arrangement of cytoplasmic components occur under control of genes." "n

Goldschmidt thus saw genes as controlling the production and distribution of cytoplasmic materials, but he did not see the cytoplasm as controlling the nucleus. That reciprocal relationship, alluded to in the earlier discussion of the views of Morgan and Driesch, had been abandoned by Goldschmidt and Just. Whereas Just made the relationship vectoral, with the cytoplasm influencing the nucleus only, for Goldschmidt the nucleus influenced the cytoplasm, and the cytoplasm did as the nucleus demanded.

In Goldschmidt's model of the embryonic cell, the cytoplasm is the substratum upon which the genes act. It is not, itself, active. In all cases, the cytoplasm was considered to be the substratum on which the genes work, although the processes within the cytoplasm may take this independent course once started by the action of the genes. The word substratum is well chosen, for it not only denotes the background on which genes act, but it also connotes an enzymatic property as well. Genes act on the substratum-cytoplasm as enzymes act on substrates. The activation of the gene, then, is merely the preparation of the substrate. In the dividing egg, "one substratum is transformed into two or more different ones, which now provide the proper substratum for 
the activation of new genes." This process does not necessarily mean that some new cytoplasmic stuff feeds back into the nucleus to activate a specific gene. Rather, Goldschmidt's cytoplasmic "preparations" for gene activity include alterations of $\mathrm{pH}$, temperature, and the presence of correct cofactorsprecisely those elements that allow enzymes to react on substrates. The cytoplasm, then, exists to be modified by the action of the nucleus. It is a series of substrates to be acted upon by the gene-enzyme agents derived from the nucleus. "Thus we conclude that the cytoplasm is mainly the substratum for genic action, in which all those decisive processes take place which constitute development and which are steered by the genes." 78

In Goldschmidt's model, the cytoplasm carries no potentials. It is impotent and subservient, a far cry from the potent, active cytoplasm proposed by Just; and its passivity is equally political. Goldschmidt's book can also be read as science, as professional polemic, and as utopian fantasy. Goldschmidt was the head of a genetics department and a firm believer in the reducibility of all developmental problems to genetic ones. Were genetics and embryology to be reunited, the geneticists would control the field. The relationship between nucleus and cytoplasm parallels that of geneticist and embryologist.

There is a political element here, as well. Goldschmidt viewed the cell as a monarchy run by the nucleus. This analogy was not peculiar to Goldschmidt. One finds it in other German biologists, and it is explicit in the work of Goldschmidt's advisor, Richard Hertwig. Writing on "Die Protozoen und die Zelltheorie" in the first article of the Archiv für Protistenkunde, Hertwig states that "I would like to compare the one-nucleus cell to an absolute monarchy; the achievements of such a political system result from the mass of people, the directives from monarch." ${ }^{79}$ Hertwig compared multinucleated cells with oligarchies, emphasizing that the nucleus always gives directives such that "nothing would change in the unitedness of a political system, even if the "oligarchs' allowed a division of labor to enter the leading roles."

This view of the nobility of the nucleus was agreeable to Goldschmidt's view of both himself and science. Richard Goldschmidt strove for a noble life. He considered himself an aristocrat, a self-aware king in the scientific world of interbellum Germany. Goldschmidt felt that artists and scientists were the truly free individuals, persons whose creative talents were responsible to no one. Indeed, the scientist and the artist were merged in Goldschmidt's personality. When Goldschmidt met Segovia in Japan, the latter gave him a personal concert. "Only kings used to be able to have such an experience." This ability to "create without outside interference or control" gave the scientist the royal duties of noblesse oblige. ${ }^{80}$

Goldschmidt as head of the genetics division of the Kaiser-Wilhelm Institute, a world-famous lecturer, art collector and critic, music connoisseur, and founder of journals, prized excellence. In his autobiography, his favorite most highly prized adjective is "noble." This word referred to spiritual rather 
than to worldly excellence, and he used it to describe individuals such as his father, nursemaid, or best childhood friend who had lived lives of hardship. ${ }^{81}$ This nobility of spirit is stressed by those individuals who remember Goldschmidt well.

Goldschmidt shocked his contemporaries by attributing this nobility to his Jewish background, and he began his autobiography with a mythic pedigree that emphasized his Jewishness.

I come from an old German-Jewish family. This fact may convey little meaning to most people, for it is perhaps not generally known that the German Jews are a group of people who can trace their origin, at least in a general way, farther back into gray antiquity than the oldest known family, the K'ung (Confucius) in China. The reason this can be done is that many German-Jewish families, like my own, belong to the caste of the Levites, the literary and teaching caste since Moses' time some three thousand years ago. The Levites kept to themselves through the centuries except for intermarriage with the priestly caste, the Cohens, and thus the members of the Levite caste are the product of an age-long selection of intellectual performance. ... When the Romans had conquered Germany and erected the Limes Germanicus, the fortified frontier against the barbarians, Roman Jews of Levite families were settled along the Limes to teach the savage Teutons the amenities of Mediterranean agriculture ${ }^{82}$

This is a truly royal pedigree wherein Goldschmidt claimed that he was not merely the fortuitous product of German high culture; rather, he was one whose ancestors created it, instructing the barbaric tribes in the ways of civilization. Moreover, Goldschmidt saw himself as the culmination of centuries of selective breeding for high intelligence. He returned to this idea later when he reflected upon a poster that the Nazis had circulated which showed all the positions of authority occupied by the Goldschmidt family. "I think that the Nazi poster could well be used as a chart demonstrating the effect of long selection of favorable hereditary traits upon the improvement of human families." 83

Kingship metaphors abound in Goldschmidt's writing. One of the most revealing is Goldschmidt's rationale for expanding genetics into embryology, for it depicts an active genetics and a passive embryology. The latter was represented as tillable land: "geneticists will continue to worry about the problem of genetic action and take the risk of climbing over the fence erected by some jealous embryologists, who, while claiming the kingdom for themselves, do not set out to till its soil." 84

Goldschmidt considered himself an aristocrat of the spirit. At the same time, he had good reason to fear the proletariat, for he had been a victim of two instances of mass hysteria. In 1918, while at Yale, Goldschmidt was arrested as "an extremely dangerous German" and was sent, under armed 
guard, to an internment camp in Georgia. Although he blamed the war-fever on the Justice Department and popular press, he found that the American public was only too willing to become a hateful mob. His supporters had to fear mob violence and personal attacks, said Goldschmidt, and "their noble actions brought many unpleasant experiences upon them during the following year." ${ }^{85}$ He also recounted the servility and readiness with which the German people accepted Hitler, and related how nobody protested the mass murders and how one widow quietly accepted her husband's death. Decent people, he reflected, are capable of the most horrible atrocities. To Goldschmidt, there is no inherent nobility in the great masses of people, and most of them will do whatever is in accord with popular fashion. They are not in control of their own destiny or even, it would seem, of their own behavior. If their leaders say it is permissible to murder, they do not protest. If the leaders wish to intern an individual away from his family, so be it. Goldschmidt had little respect for the masses, but he had enormous respect for those noble individuals who could rise above popular prejudices.

Such an ideology is reflected in Goldschmidt's cell. The world of nature is harmonious, and Goldschmidt gloried throughout his autobiography on the bountiful beauty of nature. Likewise, the cell is a marvel of harmonious function. To Goldschmidt, the nucleus was the repository of the hereditary traits. As an intellectual aristocracy passed cultural traditions to a society, so the genes expressed their inherited potentials to the cell. The cytoplasm merely allowed these traits to be expressed. All the important elements in the cell were nuclear; the cytoplasm was merely a substrate. According to Goldschmidt, development was based on the harmonious reaction system comprised of all the genes. These genes were also enzymes, and they accomplished their cytoplasmic catalyses according to the law of mass action. In the case of the embryo, the nucleus acted as the enlightened monarch should, creating a well balanced cell that performed its proper function. In mutants, the monarch was less enlightened, and the instructions to the cytoplasm could cause the death of the cell or even the death or malformation of the entire organism. But sometimes, a mutation could arise that might change the fate of a cell to something even better. This was Goldschmidt's view of evolution and it was based on nuclear homoeotic mutations. While Just viewed evolution as the product of the cell cortex, Goldschmidt viewed evolution as being controlled totally by nuclear changes.

\section{Epilogue: The Cell As Text}

We know cells only through interpretation. Nobody has knowledge of the cellular structure and function except through technical (stains, microscopy) or literary devices (textbooks, articles). Just and Goldschmidt each interpreted 
cells in different ways and for different reasons. The creative interpretation of the cell can be seen in what is left out as well as what is included in their respective discussions. Just, for instance, never used the term "segregation" in his book even though it was widely used by his colleagues and was, in fact, Lillie's paradigm for early embryonic development. Just also did not discuss Hämmerling's Acetabularia experiments, although they were well publicized. These experiments would not fit his cytoplasmic model. Similarly, we see Goldschmidt's varied interpretation of the cell in his description of Morgan's theory of the gene as being "dead as the dodo" and his interpretation of Hämmerling's experiments in terms of nuclear dominance.

Landau has shown how scientists often use narrative structure in their texts to make political stories out of their data ${ }^{86}$ This is certainly true of Just and Goldschmidt. Just casts his book within two narratives. The first is the "Ugly Duckling" story wherein the despised character is belatedly recognized as the most treasured. The hero of this tale is alternately the cell surface and Just himself, the unrecognized genius. The second narrative is the "Emperor's New Clothes" wherein Just is seen as having the keen eyes, unclouded judgment, and personal integrity to shout that the genetic theory of mutations and development is a sham. Goldschmidt's narrative is more subtle, yet is just as pervasive. The reader of Physiological Genetics cannot help but see Goldschmidt's pioneering work described on nearly every page. He refers to "the gene of tomorrow" and to "tomorrow's theory of the germ plasm." He even discusses the chemistry of chromosome replication, but then says, "I shall not develop further this idea, to which I think the future belongs." ${ }^{87}$ Goldschmidt portrayed himself as leader and prophet. Like Moses, he could lead people to the promised land, but he could not enter it himself. The American geneticists were given an opportunity to travel with him.

The Americans rejected it. They rejected both Just's and Goldschmidt's work as irrelevant. At the same time that Just and Goldschmidt published their syntheses, the British biologist Waddington published his own synthetic scheme, Organisers and Genes. This book reflected the dialectical Whiteheadian views of its author, who saw the nucleus and cytoplasm (and genetics and embryology) as mutually interacting partners. Moreover, neither genetics nor embryology was seen as sufficient to explain development. "A coherent theory of development cannot be founded on the known properties of genes. . . . No stimulus, nor single cause is itself an adequate explanation of anything." 88

Waddington attempted to show that the geneticist's genes were the same as the embryologist's organizers. Although the attempt proved problematic, it led to a rapprochement between genetics and embryology. Each discipline explained part of development and neither could subsume the other. Thus, each could pursue its own program of research. The truce fit the American setting where the newly organized science of genetics was finding research funds and backing from sources quite separate from those of embryology (see Paul and 
Kimmelman, this volume). While American embryology continued to have its roots in a European context, genetics had become a markedly different science and had separated itself from its European parentage.

\section{Acknowledgments}

I would like to thank several people for reviewing the manuscript and providing both perceptive comments and new leads to follow; N. J. Berrill, Marion Faber, Bentley Glass, Donna Haraway, John Harwood, Evelyn Fox Keller, Kenneth Manning, Jane Oppenheimer, Marsha Richmond, Jan Sapp, Peter Taylor, and the participants of the Friday Harbor conference all provided invaluable assistance.

\section{Notes}

1. Johannes Holtfreter, "Address in Honor of Viktor Hamburger," in Michael Locke, ed., The Emergence of Order in Developing Systems. The Twenty-Seventh Symposium of the Society for Developmental Biology (N.Y.: Academic Press, 1968), p. xi.

2. Scott F. Gilbert, "The Embryological Origins of the Gene Theory," Journal of the History of Biology, 1978, 11: 307-351.

3. T. H. Morgan, "Chromosomes and Heredity," American Naturalist, 1910, 44: 449-496.

4. Jan Sapp, "The Struggle for Authority in the Field of Heredity, 1900-1932: New Perspectives on the Rise of Genetics," J. Hist. Biol., 1983, 16: 311-342, and Garland Allen, "T. H. Morgan and the Split between Embryology and Genetics, 1910-1935," in T. J. Horder, J. A. Witkowski, and C. C. Wylie, eds., A History of Embryology (Cambridge: Cambridge University Press, 1985), pp. 113-146.

5. T. H. Morgan, The Theory of the Gene (New Haven: Yale University Press, 1926), p. 27.

6. Boris Ephrussi, "The Cytoplasm and Somatic Cell Variation," Journal of Cellular Comparative Physiology, 1958, 52 (suppl.): 35-54.

7. Frank R. Lillie, "The Gene and the Ontogenetic Process," Science, 1927, 66: $361-368$.

8. Ibid., pp. 362 and 365.

9. T. H. Morgan, Embryology and Genetics (New York: Columbia University Press, 1934), pp. vi and 9.

10. Ibid., pp. 9-10.

11. Hans Driesch, Analytische Theorie Organischen Entwicklung (Leipzig: Wilhelm Engelmann, 1894), quoted in Jane Oppenheimer, Essays in the History of Embryology and Biology (Cambridge, Mass.: MIT Press, 1967), p. 76.

12. Morgan, Embryology and Genetics, pp. 9 and 234.

13. Sapp, "The Struggle for Authority."

14. C. H. Waddington, An Introduction to Modern Genetics, (London: Allen and Unwin, 1939), p. 135. Waddington began the section on genetics and development: "Now that the mechanism of inheritance is known, in its main outlines at least, it is 
possible to tackle the next question, of how the genes affect the developmental processes which connect the fertilized egg into the adult organism."

15. G. W. Beadle and Boris Ephrussi, "The Differentiation of Eye Pigments in Drosophila as Studied by Transplantation," Genetics, 1936, 21:225-247. The separation of physiological genetics from what we now call "developmental genetics" had not yet occurred. To wit, the title of Goldschmidt's work, Physiological Genetics, concerns itself with what we now would call developmental genetics. The term "physiological" connoted "modern," and was itself a put-down of what Goldschmidt considered the boring, static, descriptive genetics of the Morgan school. The Ephrussi papers did not, contrary to the interpretation found in contemporary genetics texts, attempt to integrate genetics with biochemistry. Rather, Ephrussi sought "to lay a bridge between causal embryology and genetics." His techniques were those of the embryologists (transplantation) rather than those of the geneticist (breeding), and he explicitly looked at these pigment phenomena in terms of development and differentiation, using the term "inducer" to refer to the substance made by the wild type $c n$ gene. A study of Ephrussi's role in integrating genetics and developmental physiology is being prepared by Richard Burian, Doris Zallen, and J. Gayon.

16. E. E. Just, "A Single Theory for the Physiology of Development and Genetics," Am. Nat., 1936, 70: 267-312.

17. Ross G. Harrison, "Embryology and Its Relations," Sci., 1937, 85: 369-374.

18. Ibid., p. 372.

19. N. J. Berrill, personal communication, April 1985.

20. N. J. Berrill, "Foreword," Growth, 1927, I (suppl.): i. In 1927, Lillie had reflected that "genetics has become quite a unitary science, and the physiology of development is at most a field of work." It was Berrill, however, who pronounced the wittiest put-down of the geneticists: "So much has been said of the role of genes that one is tempted to define them as statistically significant little devils collectively equivalent to one entelechy." This rejoinder was published in Berrill, "Spatial and Temporal Growth Patterns in Colonial Organisms," Growth Symposium, 1941, 3: 110. For more information on this period, see Jane Oppenheimer, "The Growth and Development of Developmental Biology," in M. Locke, ed., Major Problems in Developmental Biology. The Twenty-Fifth Symposium for the Society of Developmental Biology (New York: Academic Press, 1966), pp. 1-28.

21. Berrill, "Foreword," p. i. For Schotte's version of how embryologists and geneticists alternatively represented the cell see Klaus Sander, "Genome Function in Sea-Urchin Embryos: Fundamental Insights of T. Boveri's Reflected in Recent Molecular Discoveries," in Horder, A History of Embryology.

22. J. Harwood, "The Reception of Morgan's Chromosome Theory in Germany: Debate over Cytoplasmic Inheritance," Medical History, 1984, 19: 3-32.

23. Ibid., p. 24.

24. Philip J. Pauly, "American Biologists in Wilhelmian Germany: Another Look at Innocents Abroad" (unpublished manuscript).

25. T. H. Morgan, "Genetics and the Physiology of Development," Am. Nat., 1926, 60: 459-515.

26. Hans Spemann, Embryonic Induction and Development (New Haven: Yale University Press, 1938), pp. 210-211.

27. Paul Weiss, Principles of Development (New York: Holt, 1939). 
28. Richard B. Goldschmidt, "Some Aspects of Evolution," Sci., 1933, 78: 539-547 and idem, Physiological Genetics (New York: McGraw-Hill, 1938).

29. Richard B. Goldschmidt, The Material Basis of Evolution (New Haven: Yale University Press, 1940), p. 212.

30. Goldschmidt, Physiological Genetics, p. 310.

31. Stephen Jay Gould, "Introduction," in Richard B. Goldschmidt, Material Basis of Evolution, 1940 (reprint; New Haven: Yale University Press, 1980), pp. xiv $-\mathrm{xv}$.

32. Stephen Jay Gould, "The Return of Hopeful Monsters," Natural History, 1986, June/July: 22-30.

33. Richard B. Goldschmidt, In and Out of the Ivory Tower (Seattle: University of Washington, 1960), p. 76.

34. Paul Weindling, "Theories of the Cell State of Imperial Germany," in C. Webster, ed., Biology, Medicine, and Society, 1840-1940 (Cambridge: Cambridge University Press, 1981), pp. 99- 155.

35. Kenneth R. Manning, Black Apollo of Science: The Life of Ernest Everett Just (Oxford: Oxford University Press, 1983).

36. E. E. Just, "Die Rolle des kortikalen Cytoplasmas bei vitalen Erscheinungen," Natur Wissenschaften, 1931, 19:953-962, 980-984, 998-1000, and idem, The Biology of the Cell Surface (Philadelphia: P. Blakiston's Son \& Co., 1939), pp. 337-339.

37. Just fared better among the Europeans than with the American researchers. Of the three Americans who emphasized the cell surface, R. Chambers, A. Tyler, and P. Weiss, only Tyler quoted Just, and only in reviews. At the 1940 meeting of the Cold Spring Harbor Symposium for Quantitative Biology, which focused on the cell periphery, Just's work was mentioned only once. However, Johannes Holtfreter's groundbreaking paper, "The Properties and Functions of the Surface Coat of Amphibian Embryos," Journal of Experimental Zoology, 1943, 93: 251-323, cited Just's book in five separate places and also quoted two of his research papers approvingly. Moreover, Holtfreter agreed with Just's suggestion that sublethal cytolysis could activate the egg to undergo fertilization reactions. This may have been a source of Holtfreter's later view in 1947 that the induction of the neural tube is occasioned by sublethal cytolysis, for although he did not quote Just directly in the later paper, Holtfreter claimed that the concept of sublethal cytolysis "would link up the mechanism of neural induction with that of parthenogenesis where the response is likewise determined by specific intrinsic factors rather than by the nature of the external stimulus." This is the last evidence I have been able to find of Just's work stimulating new research. After that, it remained ignored until very recently. See also Holtfreter, "Neural Induction in Explants which Have Passed through a Sublethal Cytolysis," J. Exp. Zool., 1947, 106: 197-222.

38. Goldschmidt, Ivory Tower, pp. 7-8.

39. Manning, Black Apollo, p. 194.

40. Joseph Needham, Order and Life (New Haven: Yale University Press, 1936), p. 99.

41. Kenneth R. Manning, personal communication. This is also a persistent theme in Manning's book, $n$. 35.

42. Goldschmidt, Physiological Genetics, pp. 3 and 23-51.

43. Goldschmidt and Just present excellent case studies of outsiders in science. Their creativity probably did not derive from their respective Jewish or black back- 
grounds. Rather, it may have been caused by their motives for entering biology, and development in particular. When they entered upon this science, neither of them could have hoped to become successful. Moreover, both could have gone to medical school where their chances of success were much greater. This suggests that they entered science for highly personal aesthetic or political reasons. Those reasons may not have been shared by their more mainstream colleagues.

44. "Nature has neither kernel nor shell, but is everywhere in everything." This quotation, from Just, The Biology of the Cell Surface, pp. 7-8, uses the same language to describe the nucleus and cortex of the cell.

45. Ibid., pp. 7-8.

46. Ibid., pp. 321 and 325.

47. Ibid., p. 321.

48. Ibid., pp. 57, 182, and 267.

49. Ibid., pp. $28-29$, and 46.

50. Ibid., p. 21. This attitude is precisely the reverse of Curt Stern's verdict on Goldschmidt who, he said, "served Nature, but also tried to dominate her." Curt Stern, "Richard Benedict Goldschmidt," National Academy of Sciences Biographical Memoirs, 1967, 39: 141-192.

51. Just, The Biology of the Cell Surface, pp. 18, and 30-31.

52. Goldschmidt, The Material Basis of Evolution, p. 2.

53. E. E. Just, "The Relationship of the First Cleavage-plane to the Entrancepoint of the Sperm," Biological Bulletin, 1912, 22: 239-252.

54. E. E. Just, "Initiation of Development in Nereis," Biol. Bull., 1915, 28: 1-17. See also Scott F. Gilbert and J. P. Greenberg, "Intellectual Traditions in the Life Sciences. II. Stereocomplementarity," Perspectives in Biology and Medicine 1984, 28: $18-34$.

55. Although their differences concerning fertilization are enormous and they developed animosity toward each other, the views of Just and Loeb concerning the relationship of embryology and genetics appear rather similar. According to Philip Pauly, Controlling Life: Jacques Loeb and the Engineering Ideal in Biology (NY: Oxford University Press, 1987), pp. 148-149, Loeb was never quite sure where Morgan's genetics fit into dynamic biology, but he generally believed that the egg cytoplasm controlled most of development whereas the nuclear genes added the finishing touches.

56. Just, The Biology of the Cell Surface, pp. 6-7.

57. Frank R. Lillie, "Studies of Fertilization, VI. The mechanism in Arbacia," J. Exp. Zool., 1914, 16: 523-590.

58. E. E. Just, "The Production of Filaments by Echinoderm Ova as a Response to Insemination, with Especial Reference to the Phenomenon as Exhibited by the Ova of the Genus Asterias," Biol. Bull., 1929, 57: 311-325.

59. Just, The Biology of the Cell Surface, p. 146.

60. E. E. Just, "Experimental Production of Polyploidy in the Eggs of Nereis limbata by Means of Ultraviolet Radiation," Anatomical Record, 1926, 34: 108.

61. E. E. Just, "On the Origin of Mutations," Am. Nat., 1932, 66: 61-74.

62. Just, The Biology of the Cell Surface, p. 70.

63. Ibid.

64. Ibid., pp. 326, 329. Just was not outside the biological mainstream when he 
made this hypothesis. In 1938 Curt Stern, in his paper "During Which Stage in the Nuclear Cycle do the Genes Produce their Effects in the Cytoplasm?" Am. Nat., 1938, $72: 350-357$, said the possibility that the nucleus specifically extracts materials from the cytoplasm during development cannot be ruled out. This again is a German, not American, approach to nucleocytoplasmic relationships. Just's debt to the German geneticists is also seen in his 1936 article, "A Single Theory for the Physiology of Development and Genetics," Am. Nat., wherein he stated that his aim was to place genes "within the domain of physiology." This, of course, was also Goldschmidt's aim.

65. Ibid., p. 326.

66. Ibid., pp. $365-367$. The concept of the organism as a society of cells was central to German biology. The transformation of this Zellenstaat from liberal republic to authoritarian dictatorship is documented in Weindling, "Theories of the Cell State in Imperial Germany."

67. W. C. Allee, Animal Life and Social Growth (Baltimore: William \& Wilkins, 1932), pp. 157-159, 200. Allee claimed that primitive societies, like primitive organisms, are authoritarianly ruled from the brain. As both organisms and societies evolved, more interaction occurs between components and "social control tends to become less autocratic and more democratic. . . The highest organizations even tend to dispense with leadership."

68. W. E. B. DuBois, Darkwater: Voices from Within the Veil (New York: Harcourt, Brace, 1921), p. 151.

69. W. E. B. DuBois, The Souls of Black Folk (1903), quoted in A. Chapman, Black Voices (New York: Mentor), p. 496.

70. This self-identification and love of a scientist with his or her object of study is not uncommon. For an uncommonly candid account of this phenomenon, see June Goodfield, An Imagined World (New York: Harper and Row, 1981), p. 229. This same theme is expressed in Evelyn Fox Keller, A Feeling for the Organism (San Francisco: W. H. Freeman, 1983), pp. 204-206.

71. Goldschmidt, Physiological Genetics, pp. $\mathrm{v}$ and 1.

72. Ibid., p. 200.

73. Ibid., p. 251.

74. Ibid., pp. 208-209.

75. Ibid., pp. 3 and 51.

76. J. Hämmerling, “Über formbildende Substanzen bei Acetabularia mediterranea, ihre ranmliche und zeitliche Verteilung und ihre Herkunft," Archiv für Entwicklungmechanik, 1934, 131: 1-81.

77. Goldschmidt, Physiological Genetics, pp. 193 and 179.

78. Ibid., pp. 263, 266, and 280.

79. Richard Hertwig, "Die Protozoen und die Zelltheorie," Archiv für Protistenkunde, 1907, 1:1-40.

80. Goldschmidt, Ivory Tower, pp. 69 and 246.

81. Ibid., pp. 29, 33, 38, and 69.

82. Ibid., p. 3.

83. Ibid., p. 5 .

84. Richard B. Goldschmidt, Theoretical Genetics (Berkeley: University of California Press, 1955), p. 247. 


\section{Scott F. Gilbert}

85. Ibid., p. 169.

86. Misia Landau, "Human Evolution as Narrative," American Scientist, 1984, 72: 262-268.

87. Goldschmidt, Physiological Genetics, pp. 301 and 314.

88. C. H. Waddington, Organisers and Genes (Cambridge: Cambridge University Press, 1940), p. 3. 